\title{
THE MEASUREMENT OF C-REACTIVE PROTEIN IN HUMAN SERA. COMPARISON OF THE CLINICAL TESTS ON THE BASIS OF A QUANTITATIVE METHOD
}

\author{
By HARRISON F. WOOD AND MACLYN MCCARTY
}

(From the Hospital of The Rockefeller Institute for Medical Research, New York, N. Y.)

(Submitted for publication January 31, 1951; accepted, April 9, 1951)

C-reactive protein is a substance which appears in the blood in the course of a variety of disease processes. The existence of this protein in serum was first recognized as a result of its property of reacting to form a precipitate in the presence of the somatic $\mathrm{C}$ polysaccharide of Pneumococcus (1), and this reaction is responsible for the name which is at present used for the protein. Since the original description of the reaction, a number of papers have appeared concerning the purification and properties of this protein, and the range of diseases in which it is present in the blood (2-6).

The determination of $\mathrm{C}$-reactive protein in the blood as a measure of the activity of the disease process in acute rheumatic fever has been described by Anderson and McCarty (7). In this instance, a specific rabbit antiserum to human $\mathrm{C}$ reactive protein was employed to detect the presence of the protein in patients' sera by means of a precipitin test, and the results of this test were correlated with clinical and other laboratory data in a series of 45 patients with acute rheumatic fever. Like the erythrocyte sedimentation rate and the white blood cell count, the test for C-protein is not a diagnostic test for rheumatic fever, since it is positive in other infectious and non-infectious diseases. However, in this series of cases it appeared to be a more sensitive index of disease activity than any other that was available.

The antigen-antibody test for estimating C-reactive protein is extremely sensitive in detecting small amounts of the substance in serum, but the procedure used is at best only semi-quantitative. The results are recorded on the basis of the volume of precipitate formed, ranging from zero in the absence of reaction to ++++++ in the case of a maximal reaction. It is obvious that readings of this sort may not be the same when made by different observers, and furthermore different lots of antiserum vary in the amount of precipitable antibody which they contain. In the present study an attempt has been made to obtain a more quantitative estimate of the amount of C-protein present in various sera, and to correlate the quantitative data with the results of the precipitin reaction.

The general use of the C-protein precipitin test with rabbit antiserum as a clinical laboratory test in rheumatic fever is at present limited because of the difficulties involved in obtaining pure Cprotein preparations in quantities which allow large scale production of rabbit antiserum. An alternative to the use of rabbit antiserum for the detection of the C-reactive protein in serum is the original precipitation reaction which employs the relatively easily prepared $\mathrm{C}$ polysaccharide of the Pneumococcus (8). The latter reaction is best performed as a ring test in which a dilute solution of the carbohydrate is carefully layered on the serum to be tested. A visible precipitate forms at the interface, and the density of the ring is roughly proportional to the amount of C-protein present in the serum. The reaction is never obtainable between $\mathrm{C}$ polysaccharide and normal serum. Many earlier determinations done in this laboratory indicated that the carbohydrate does not give a visible reaction in the presence of low concentrations of C-protein which are readily detectable with the antiserum. In the present study a comparison of the sensitivity of the two indicator systems, C carbohydrate and antiserum, is presented.

Because the capillary precipitin reaction between the C-protein of serum and the rabbit antiserum is only roughly quantitative, the desirability of determining the actual amount of protein responsible for the different titers of precipitin reaction given by patients' sera is evident. This determination has been undertaken in the present study.

\section{MATERIALS AND METHODS}

Rabbit antiserum to $C$-reactive protein. The antiserum was obtained by injecting rabbits intravenously with a preparation of human C-protein purified by the method 
of MacLeod and Avery $(3,4)$. This preparation was almost completely free of normal human serum proteins. The antiserum reacted slightly with normal human serum, and the cross-reacting antibody was completely removed by adsorption with dried normal human serum protein.

Precipitin test with antiserum. The precipitin tests with antiserum were carried out in capillary tubes according to the procedure described by Anderson and McCarty (7). This method is based on the capillary precipitin technique for serologic typing of group A streptococci described by Swift, Wilson and Lancefield (9).

Pneumococcal Cx polysaccharide. This polysaccharide was prepared by rapid lysis and deproteinization of the pneumococcal cells, as recently described by Anderson and McCarty (10). It is identical with classical C polysaccharide in the sensitivity of its reaction with human $\mathrm{C}$-reactive protein, and either one can be used to react with and remove the $C$-protein from serum.

The $C_{x}$ carbohydrate used in this work was free of protein and nucleic acid, and the analysis of its nitrogen and phosphorus content agreed closely with elementary analyses previously done on other samples of the carbohydrate.

Ring tests with $C x$ polysaccharide. The reactions between serum and $\mathrm{Cx}$ polysaccharide were carried out in pointed precipitin tubes in which approximately $0.1 \mathrm{cc}$. of an $0.1 \mathrm{mg}$./cc. Cx carbohydrate solution in $0.85 \%$ $\mathrm{NaCl}$ was very carefully layered over $0.1 \mathrm{cc}$. of the serum being tested. Each determination was controlled with a tube containing the test serum layered with $0.85 \% \mathrm{NaCl}$ in place of the carbohydrate. After incubation for one hour at $37^{\circ} \mathrm{C}$. the tubes were inspected for the appearance of a ring of visible precipitate at the interface.

Patients' sera. The specimens of serum used in this study were from 200 serial weekly bleedings on 18 patients with acute rheumatic fever, and from 68 bleedings on 18 patients with viral hepatitis. The patients studied were under observation and treatment in the Hospital of The Rockefeller Institute for Medical Research.

Quantitative measurement of C-reactive protein. The quantitative method for the determination of $\mathrm{C}$-reactive protein depends on the spectrophotometric estimation of the amount of protein removed from serum by the addition of $\mathrm{Cx}$ polysaccharide. The following procedure is employed.

All sera are cleared by centrifugation if necessary. Samples of $0.4 \mathrm{cc}$. of serum are mixed with $0.4 \mathrm{cc}$. of an $0.1 \mathrm{mg}$./cc. solution of $\mathrm{Cx}$ polysaccharide in $15 \mathrm{cc}$. pointed centrifuge tubes. After incubation for one to two hours, the tubes are refrigerated overnight. The precipitate is thrown down by centrifugation and is washed three times with $5 \mathrm{cc}$. volumes of $0.85 \%$ sodium chloride containing $0.01 \%$ calcium chloride. The presence of calcium ion is essential to prevent any resolution of the precipitate during the washing process. The washed precipitate is redissolved in $0.2 \mathrm{cc}$. of $0.1 \mathrm{M}$ sodium citrate and the solution is placed in a quartz micro-cell for measurement of the ultraviolet adsorption at $280 \mathrm{~m} \mu$. In most cases the precipitate dissolves completely to give a clear solution, and if particulate material is present it is necessary to clear the solution by centrifugation before testing. In the concentrations used, the $\mathrm{Cx}$ polysaccharide does not show measurable adsorption in the ultraviolet, and the optical density of the polysaccharide-protein solution at this wave length is proportional to the concentration of protein.

Two aspects of the validity of this quantitative procedure were checked by serological methods. First, although previous experience indicated that a single concentration of $\mathrm{Cx}$ polysaccharide $(0.1 \mathrm{mg} . / \mathrm{cc}$.) could serve as the precipitant throughout the entire range of C-protein concentrations expected in sera, this was further checked by submitting the serum supernatants (after removal of the C-protein-polysaccharide precipitates) to the sensitive antibody test for C-protein. It was found that the $0.1 \mathrm{mg} . / \mathrm{cc}$. solution of polysaccharide removed practically all of the C-protein from sera containing the highest concentrations and showed no evidence of proconing with sera containing smaller amounts. Secondly, it was important to determine whether the washed Cprotein-polysaccharide precipitates contained appreciable quantities of serum proteins other than $\mathrm{C}$-reactive protein. This point was investigated by testing the redissolved precipitate by the precipitin method with high-titered rabbit antiserum prepared against normal human serum. Only negative or trace reactions were obtained in these tests, indicating that normal serum proteins were probably not present in amounts sufficient to affect the spectrophotometric readings.

The results obtained by this quantitative procedure do not appear to be influenced by the presence of antibody to pneumococcal $\mathrm{C}$ polysaccharide. This antibody was shown by Heidelberger, MacLeod, Kaiser, and Robinson to be present in most human sera in significant amounts (11). The fact that antibody does not interfere with the measurement of C-reactive protein is probably best explained by the following considerations: In the quantitative measurement of $\mathrm{C}$ antibody, Heidelberger and his associates found it necessary to use long periods of refrigeration (eight days or longer) to obtain complete precipitation by the polysaccharide, while in the case of $\mathrm{C}$-reactive protein refrigeration overnight is sufficient; and furthermore if antigen-antibody precipitates were formed in the course of the procedure described above, they would not redissolve in the citrate solution and would be removed by centrifugation before the spectrophotometric measurement was carried out.

Standardization of the spectrophotometric measurement of $C$-reactive protein. For the purpose of calculating the actual protein concentrations represented by the optical density measurements, a standard curve was prepared, using a large lot of purified C-reactive protein on which nitrogen analyses were carried out. The purified C-protein was obtained from $615 \mathrm{cc}$. of thoracentesis fluid from a patient with lymphosarcoma. Preliminary study of a sample of this fluid showed that the greater part of the C-protein which it contained was bound to phospholipid; and since the phosphorus and nitrogen contributed by the phospholipid would have influenced the quantitative results on elementary analysis of the purified protein, a de- 


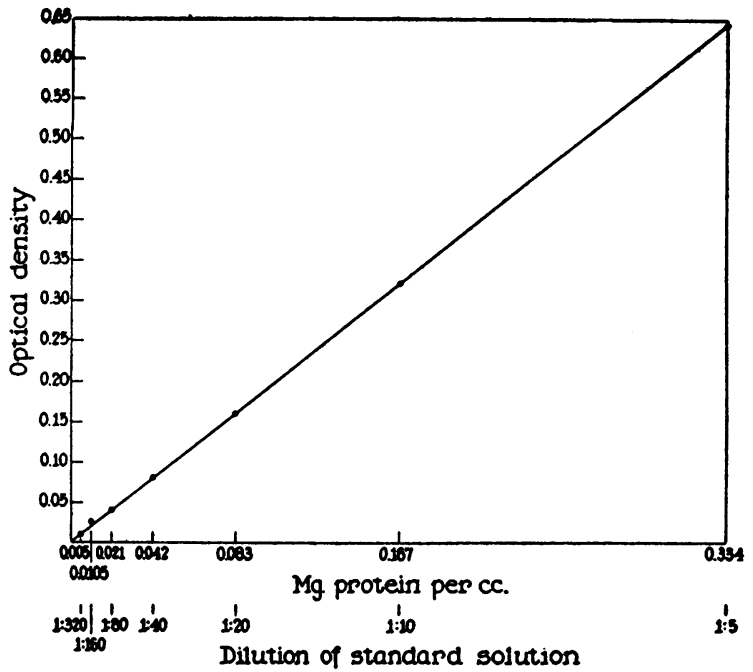

Fig. 1. The Standard Curve of the Optical DenSity Readings on the Beckman Spectrophotometer at $280 \mathrm{M} \mu$ of Dilutions of a Solution Containing a Known Amount of Purified C-Reactive Protein

fatting procedure was used. The fluid was first fractionated with ammonium sulfate and the fraction which precipitated between $0.5 \%$ and $0.75 \%$ saturation was taken up in $68 \mathrm{cc}$. of distilled water. Following dialysis of the fiaction against two changes of $1 \mathrm{M} \mathrm{NaCl}$, the preparation was defatted with alcohol and ether in the cold, as described by MacLeod and Avery (3). The dried, defatted fraction after resolution in $200 \mathrm{cc}$. distilled water contained practically all of the C-reactive protein originally present in the fluid. This solution was then dialyzed against $0.01 \%$ calcium chloride to remove any lipidbound $\mathrm{C}$-reactive protein that might have escaped defatting. The dialyzed solution was cleared by centrifugation, brought to physiological salt concentration by the addition of molar saline, and the $\mathrm{C}$-reactive protein was precipitated from the solution with $25 \mathrm{mg}$. of $\mathrm{Cx}$ polysaccharide. The protein-carbohydrate complex was washed five times in $0.85 \% \mathrm{NaCl}$ containing $0.01 \% \mathrm{CaCl}_{2}$, and finally redissolved by adding a solution $0.1 \mathrm{M}$ with respect to both sodium citrate and sodium chloride.

To obtain the values used in constructing the standard curve, the optical density of several carefully prepared serial dilutions of this final solution was measured at 280 $\mathrm{m} \mu$, and the protein nitrogen content of the material was determined. Since the $\mathrm{Cx}$ polysaccharide is a nitrogenous carbohydrate, it was necessary to correct for the nitrogen contributed by the polysaccharide. This was made possible by the fact that the polysaccharide contains phosphorus in addition to nitrogen, while C-protein does not. Thus, from the nitrogen and phosphorus analyses on the purified material and on the preparation of $\mathrm{Cx}$ polysaccharide used in the precipitation of the protein, it was possible to calculate with reasonable accuracy the amount of protein nitrogen present in the final material. It should be pointed out that the total amount of polysaccharide re- maining in the final product was small in relation to the amount of protein and represented only a fraction of the $25 \mathrm{mg}$. initially used to precipitate the protein. Consequently, the correction required for polysaccharide nitrogen was not large. The phosphorus determinations were done by the King modification of the Fisk-Subbarow method, and the nitrogen determinations by the micro Kjeldahl technique. ${ }^{1}$

Figure 1 shows the relationship between the concentrations of C-reactive protein and its adsorption at $280 \mathrm{~m} \mu$. It has previously been determined that crystalline C-reactive protein contains $14.66 \%$ nitrogen (12), and the values for protein concentration are calculated from the nitrogen values on the basis of this figure.

\section{RESULTS}

Comparison of the sensitivity of the two clinical tests for measuring C-protein in patients' sera. Consecutive weekly bleedings from 18 patients hospitalized for acute rheumatic fever were tested for the presence of $\mathrm{C}$-reactive protein both by the precipitin test with specific antiserum, and by the ring test with $\mathrm{Cx}$ carbohydrate. The results obtained with both techniques on a total of 200 sera are shown in Table I.

It is evident from the data that the test system using the antiserum is definitely and consistently more sensitive than that in which the $\mathrm{Cx}$ carbohydrate is employed. The ring test with carbohydrate cannot be used as a reliable indicator for the detection of the C-protein in sera which give less than a ++ \pm precipitin reaction with the antiserum. As shown by the quantitative data in Table IV, this indicates that a concentration of C-protein greater

1 The nitrogen analyses were made by $\mathrm{Mr}$. Theodore Bella of The Rockefeller Institute and the phosphorus analyses by Dr. Lewis K. Dahl of the Hospital of The Rockefeller Institute.

TABLE I

Comparison of the sensitivity of serum reactions of patients with rheumatic fever when tested with antiserum to human $C$-protein and with $C x$ polysaccharide

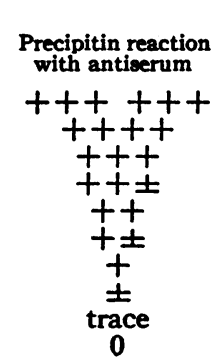

Number of sera
tested
7
9
15
9
17
8
42
32
23
38

Number of positive reactions with $\mathrm{Cx}$ carbohydrate 
than $0.05 \mathrm{mg} . / \mathrm{cc}$. is required to give a visible precipitate with the polysaccharide. Despite the failure of the carbohydrate to give visible rings of precipitate at the interface with sera containing less than the limiting concentartion of $\mathrm{C}$-protein, it is apparent from the studies using the quantitative spectrophotometric technique that the reactive protein is chemically bound to the polysaccharide and can be removed by centrifugation.

In an attempt to increase the sensitivity of the carbohydrate ring test system, the carbohydrate solutions were made up in $1 \%$ crystalline bovine albumin solution and in $1 \%$ solution of human serum fraction $\mathrm{V}$ (13). It was found that the use of albumin intensified the ring with sera known to be reactive but did not cause the formation of visible reactions with sera that failed to give a positive ring test with the carbohydrate in saline.

From the point of view of clinical application, the lower sensitivity of the test with $C$ polysaccharide greatly reduces its usefulness. This is unfortunate since the availability of $\mathrm{C}$ polysaccharide would make this procedure more feasible for general use than the test requiring specific antiserum. However, in the results described by Anderson and McCarty (7) and in subsequent studies in this laboratory, the determination of $\mathrm{C}$-reactive protein in the evaluation of rheumatic activity is frequently most helpful in those cases in which the sera fall in the lower range of the precipitin reaction where the ring test with the polysaccharide is not reliable. In cases with more marked activity of the disease process, where both tests are strongly positive, other laboratory as well as clinical evidence of activity is usually available.

In addition to the studies on sera from rheumatic fever patients, precipitin tests have been carried out with sera from patients with a variety of other diseases, and in some instances it appears that the concentration of $\mathrm{C}$-protein in the serum rarely, if ever, reaches levels that would be detectable with the $C$ polysaccharide ring test. An interesting example is provided by studies on viral hepatitis. Havens, Eichman and Knowlton (14) have recently reported the failure to demonstrate the presence of $\mathrm{C}$-protein by means of the $\mathrm{C}$ carbohydrate test in the sera of 90 patients with this disease. These workers called attention to the fact that the use of antiserum might have given different results, and this possibility has been investigated in
TABLE II

Magnitude of positive reactions between sera of patients with viral hepatitis and antiserum to human C-reactive protein
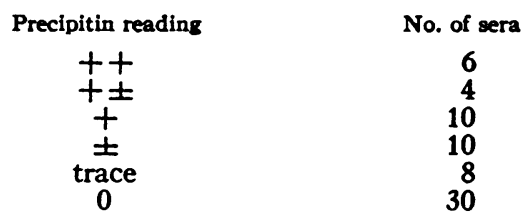

this laboratory by testing 68 sera from 18 patients with viral hepatitis in the Hospital of The Rockefeller Institute. Thirty-eight of these sera gave positive precipitin reactions with the antiserum, but, as can be seen from the data presented in Table II, none of these reactions was of sufficient intensity so that a reaction with $\mathrm{C}$ carbohydrate would be expected. The incidence of positive precipitin reactions in relation to the duration of the disease is recorded in Table III, and it is obvious that the occurrence of $C$-protein in the serum is not limited to any particular phase of the disease. It appears that the occurrence of $\mathrm{C}$-protein in the blood is a common, though not invariable, event in viral hepatitis.

TABLE III

$\begin{array}{ccc}\begin{array}{r}\text { Results of precipitin tests between } \\ \text { and sera of patients with viral hepatitis }\end{array} \\ \begin{array}{c}\text { Number of sera } \\ \text { tested }\end{array} & \begin{array}{c}\text { Number of positive } \\ \text { precipitin reactions }\end{array} \\ \text { Days of disease } & 5 & 4 \\ 1-7 & 11 & 8 \\ 7-14 & 11 & 6 \\ 14-21 & 11 & 7 \\ 21-28 & 21 & 12 \\ 28-60 & 9 & 1\end{array}$

Quantitative studies of the C-reactive protein in the serum of patients with acute rheumatic fever. Quantitative determinations of the C-reactive protein were done on the sera from serial bleedings on six patients with acute rheumatic fever. The concentration of the protein was calculated from the optical density readings by the use of the standard curve and was expressed in terms of $\mathrm{mg}$. of protein per cc. of serum.

In Table IV the relationship between the precipitin reactions and the results of the quantitative test is presented. The mean optical density observed in the quantitative test has been calculated for all sera giving each of the different readings in the precipitin test. 
TABLE IV

Correlation of the results of the precipitin test with the quantitative data on C-reactive protein in the sera of patients with rheumatic fever

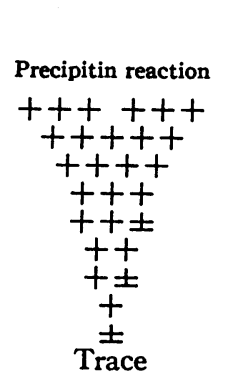

$\begin{array}{cc}\begin{array}{c}\text { Quantitative data } \\ \begin{array}{c}\text { Mean optical } \\ \text { density }\end{array} \\ \text { Mean concentration } \\ \text { of C-protein mg./cc. }\end{array} \\ 0.616 & 0.330 \\ 0.510 & 0.273 \\ 0.430 & 0.230 \\ 0.235 & 0.126 \\ 0.208 & 0.101 \\ 0.101 & 0.054 \\ 0.087 & 0.046 \\ 0.043 & 0.021 \\ 0.027 & 0.010 \\ 0.013 & 0.006\end{array}$

As indicated by these data, $1 \mathrm{cc}$. of a serum giving ++++++ precipitin reaction contains over $0.3 \mathrm{mg}$. of this abnormal serum protein. Sera obtained from patients during the most active stage of acute rheumatic fever give marked reactions ranging from ++++ to ++++++ in precipitin tests with $\mathrm{C}$-protein antiserum. On the basis of the quantitative data presented in Table IV, precipitin reactions of this order indicate that there is an appreciable total amount of C-protein in the circulating blood at the height of the disease. As recovery progresses this protein is present in decreasing amounts until it disappears from the blood completely, often before the erythrocyte sedimentation rate has returned to normal (7).

The quantitative fluctuations in C-reactive protein in the serum during the course of rheumatic fever are illustrated graphically by the charts of two patients given in Figures 2 and 3. Figure 2,

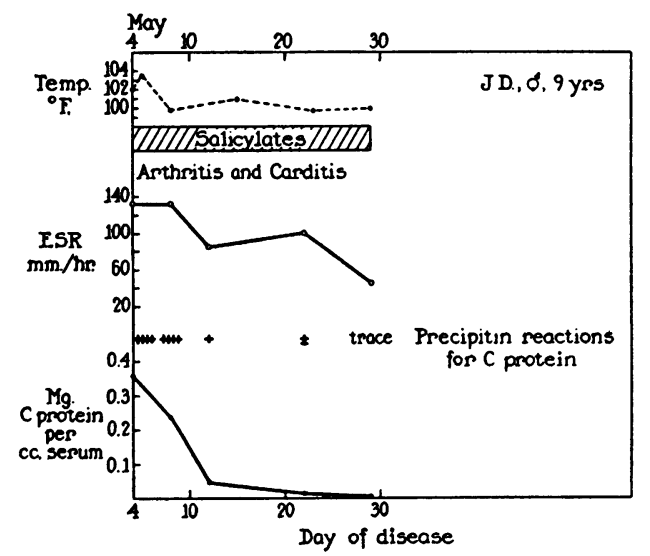

Fig. 2. Patient J. D. Variations of C-Protein in Rheumatic Fever

Correlation of C-protein determinations with other laboratory and clinical data.

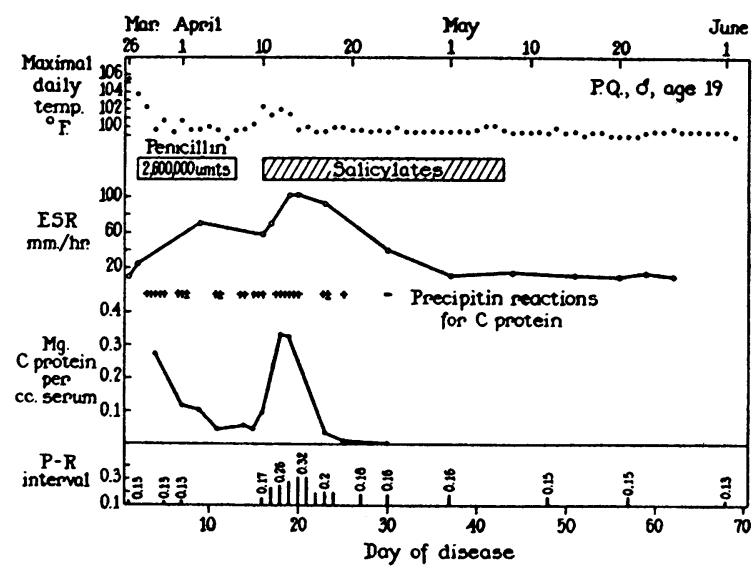

Fig. 3. Patient P. Q. Variations of C-Protein in Streptococcal Pharyngitis followed by Rheumatic Fever

Correlation of C-protein determinations with other laboratory and clinical data.

on patient J. D., illustrates a simple monocyclic pattern of rheumatic fever with major manifestations of fever, polyarthritis, and carditis. The C-reactive protein in this patient showed a sharp uninterrupted drop to zero from the high level of 0.360 mg./cc. present during the most acute phase of the illness.

In Figure 3 the variations of $\mathrm{C}$-protein concentration in the blood are illustrated in a case of streptococcal pharyngitis which was followed by a recurrence of rheumatic fever. This patient, P. Q., a known rheumatic, was admitted to the Hospital of The Rockefeller Institute on March 26, 1950, at the first appearance of sore throat, malaise, and fever. A group A, type 18 streptococcus was cultured from this patient's throat and nose. The acute pharyngitis, which was paralleled by the appearance of a high level of C-protein $(0.272 \mathrm{mg}$./ cc.), was treated with penicillin and as clinical recovery occurred, the C-protein almost disappeared. However, on the 16th hospital day, the temperature and erythrocyte sedimentation rate both began to rise. These signs, along with clinical and electrocardiographic evidence of myocarditis, were accompanied by a rapid and marked increase in the amount of $\mathrm{C}$-protein in the serum. As can be seen from the chart, the fall in concentration of $C$ protein reflected the subsidence of carditis, the only major manifestation of this patient's disease, more accurately than did the fall in the erythrocyte sedimentation rate. The biphasic nature of the curve 
of C-protein concentration is of interest with respect to the evaluation of the latent interval between the streptococcal infection and the onset of rheumatic fever. Although C-protein did not completely disappear from the blood in this instance, it had fallen sharply from $0.27 \mathrm{mg}$./cc. to $0.04 \mathrm{mg}$./ cc. in seven days before the appearance of symptoms of rheumatic fever. This rate of fall is comparable to that seen in certain cases of uncomplicated streptococcal infection. It would appear from this and other data, therefore, that there is nothing in the pattern of $\mathrm{C}$-protein response which makes it possible to predict the imminence of rheumatic fever as a complication of streptococcal disease.

\section{DISCUSSION}

As a result of the use of the quantitative procedure for the estimation of C-reactive protein, it is now possible to give reasonably accurate values for the concentration of this substance in the blood during various disease states. While the spectrophotometric method is not suggested as a routine clinical procedure, it appears to have value in the study of certain cases of special interest in which more exact data concerning the fluctuations in concentration of C-protein are desirable. Moreover, the quantitative data allow a more precise comparison of the sensitivity of the two tests which have clinical applicability, and it is apparent that the test with specific antibody is greatly superior to that with the $\mathrm{C}$ polysaccharide. The ring test with $\mathrm{C}$ polysaccharide is not consistently positive at concentrations of $\mathrm{C}$-protein below $0.1 \mathrm{mg}$./cc., while the antibody test will detect the presence of less than $0.01 \mathrm{mg} . / \mathrm{cc}$. In view of this fact, it is clear that at present the antibody procedure is the method of choice whenever the concentration of $\mathrm{C}$-protein in the blood is to be used as a reflection of the activity of a disease process.

\section{SUMMARY AND CONCLUSION}

1. A quantitative method for the determination of C-reactive protein in human serum is described. Although absent from normal serum, the protein has been shown to reach concentrations above 0.33 $\mathrm{mg}$./cc. in acute rheumatic fever.

2. The C-reactive protein may be detected semiquantitatively by its reaction with the pneumococcal $\mathrm{C}$ polysaccharide or by a precipitin test with a specific rabbit antiserum. The sensitivities of these two methods have been compared and it is shown that the reaction with $\mathrm{C}$ polysaccharide is not reliable at serum $\mathrm{C}$-protein concentrations below $0.1 \mathrm{mg}$./cc., while the rabbit antiserum gives positive reactions in the presence of less than 0.01 $\mathrm{mg}$./cc. It is concluded that the $\mathrm{C}$ polysaccharide test cannot replace the antibody test in the clinical procedure in which $\mathrm{C}$-protein is determined as a measure of rheumatic activity.

3. The sera of some patients with viral hepatitis contain C-reactive protein in concentrations high enough to be detected with the antiserum but too low to be detected by a visible reaction with the $\mathrm{Cx}$ polysaccharide. The presence of the $\mathrm{C}$-reactive protein in sera from patients with viral hepatitis is not limited to the initial acute phase of the disease.

\section{ACKNOWLEDGMENT}

The authors wish to acknowledge the able technical assistance of Miss Helen Babcock.

\section{REFERENCES}

1. Tillett, W. S., and Francis, T., Jr., Serological reactions in pneumonia with a non-protein somatic fraction of pneumococcus. J. Exper. Med., 1930, 52, 561.

2. Abernethy, T. J., and Avery, O. T., The occurrence during acute infections of a protein not normally present in the blood. I. Distribution of the reactive protein in patients' sera and the effect of calcium on the flocculation reaction with $\mathrm{C}$ polysaccharide of pneumococcus. J. Exper. Med., 1941, 73, 173.

3. MacLeod, C. M., and Avery, O. T., The occurrence during acute infections of a protein not normally present in the blood. II. Isolation and properties of the reactive protein. J. Exper. Med., 1941, 73, 183.

4. MacLeod, C. M., and Avery, O. T., The occurrence during acute infections of a protein not normally present in the blood. III. Immunological properties of the $\mathrm{C}$-reactive protein and its differentiation from normal blood proteins. J. Exper. Med., 1941, 73, 191.

5. Ash, R., Nonspecific precipitins for pneumococcic fraction C in acute infections. J. Infect. Dis., 1933, 53, 89.

6. Hedlund, P., The appearance of acute phase protein in various diseases. Acta med. Scandinav., suppl., 1947, 196, 579.

7. Anderson, H. C., and McCarty, M., Determination of C-reactive protein in the blood as a measure of the activity of the disease process in acute rheumatic fever. Am. J. Med., 1950, 8, 445. 
8. Tillett, W. S., Goebel, W. F., and Avery, O. T., Chemical and immunological properties of a speciesspecific carbohydrate of pneumococci. J. Exper. Med., 1930, 52, 895.

9. Swift, H. F., Wilson, A. T., and Lancefield, R. C., Typing group A hemolytic streptococci by $M$ precipitin reactions in capillary pipettes. J. Exper. Med., 1943, 78, 127.

10. Anderson, H. C., and McCarty, M., The occurrence in the rabbit of an acute phase protein analagous to human C-reactive protein. J. Exper. Med., 1951, 93, 25.

11. Heidelberger, M., MacLeod, C. M., Kaiser, S. J., and Robinson, B., Antibody formation in volunteers following injection of pneumococci or their type-specific polysaccharides. J. Exper. Med., 1946, 83, 303.

12. McCarty, M., The occurrence during acute infections of a protein not normally present in the blood. IV. Crystallization of the C-reactive protein. J. Exper. Med., 1947, 85, 491.

13. Wiener, A. S., Hurst, J. G., and Sonn-Gordon, E. B., Studies on the conglutination reaction, with special reference to the nature of conglutinin. J. Exper. Med., 1947, 86, 267.

14. Havens, W. P., Jr., Eichman, H. L., and Knowlton, M., Failure to find C-reactive protein in viral hepatitis. Proc. Soc. Exper. Biol. \& Med., 1950, 75, 108. 